\title{
THE SIGNIFICANCE OF THE NAME ALMUDENA IN GALDÓS' "MISERICORDIA"
}

\author{
Vernon A. Chamberin \\ University of Kansas
}

The picturesque and exotic character Almudena has long intrigued Galdosian scholars. ${ }^{*} \mathrm{He}$ has recently been illuminated and made much more understandable by the fine studies of Robert Ricard, "Sur le personnage d'Almudena dans Misericordia," and Dinah Lida, "De Almudena y su lenguaje." ${ }^{1}$ However, to date, no scholar has investigated and commented on the character's name. This seems imperative for a full understanding of the personaje because it has been repeatedly demonstrated that the names Galdós gave to his principal characters were not incidental tags, but carefully chosen appellations designed to reflect essential attributes of the character and frequently to carry additional symbolic connotations as well. ${ }^{2}$

On the surface, the name Almudena serves as a convincing bit of realism-i.e., the reader has every right to expect that a Moroccan character who comes from "Sus, tres días más allá de Marrakesh" (p. 1882), ${ }^{3}$ "pueblo de Ullah de Bergel" (p. 1912), should have an Arabic-sounding name. However, with customary Galdosian irony, the word, when investigated, turns out to be more Spanish than Arabic and is, in its present form, completely Madrilenian. It is so Madrilenian in fact that Galdós felt no need to explain it to his reader. Since 1085, citizens of Madrid have honored the Virgin as their patroness under the name Nuestra Señora de la Almudena (the latter word being derived from $\mathrm{Al}$ mudit or granary as will be explained later). ${ }^{4}$

* A paper read at the Fifth Annual Meeting of the MMLA, Normal Illinois, May 8, 1964.
The tone of Misericordia is, in many parts and in many ways, very humorous; and Almudena is, among other things, a very comical character. During the latter half of the nineteenth century, it was customary to poke fun at such Moroccan types living in the Spanish capital. An example of this may be seen in the caption accompanying a sketch in the magazine El museo universal showing " $\mathrm{El}$ vendedor de dátiles, tipo casi español muy conocido en Madrid."5 One of Galdós' characters chides Benina, the protagonist, in a similar vein for her association with "el moro de los dátiles" (p. 1982). This same jocular tone and similar nicknames occur in several parts of the novel (pp. 1911, 1952, 1982-83). Thus one perceives that Galdós was au courant regarding the tastes of his fellow Madrilenians; and, consequently, one may surmise that his contemporary readers must have been amused at seeing Galdós' colorful Moroccan beggar with the most Madrilenian of names, and under the protection of their patroness-whose name he could not even pronounce correctly: "Joseph Marien Almudena" (p. 1954). ${ }^{6}$

However, as is well known, Galdós also had deep, serious reasons for writing Misericordia. It is gęnerally accepted that the author is telling the truth when he says that he actually knew and interviewed a blind Moroccan beggar who served as the prototype for Almudena." Precisely why Galdós states that Almudena comes from the region of Sus has not yet been fully determined, especially when the blind Moor in Francisco Cutanda's Doña Francisca, el portento de la caridad ${ }^{8}$ 
demonstrated to be another probable source in Galdós' creation of Almudena-is from Tangiers (p. 126). However, since Galdós insists on Sus (pp. 1882,1912), ${ }^{9}$ it is apropos to note that in "el dialecto susi del bereber" of southern Morocco, the almuecin (or almuédano)-the man who summons the faithful to prayer from atop the minaret-is called a "lmudden." ${ }^{10}$ One of the characters in Misericordia holds the opinion that Galdós' Almudena also is a Moslem religious functionary: "era en su tierra clérigo, quiere decirse, presbítero ..." (p. 1952). Significantly, Almudena is the only character in Misericordia to be seen at prayer (pp. 1890, 1952).

However, if Galdós knew the relationship between the similar sounding words "lmudden" and Almudena-from interviewing the charcter's flesh-and-blood prototype, from reference books, or from corresponding informants ${ }^{11}$-and worked from the concept and sound of the Berber word "Imudden" (or the Spanish almuédano) to the name Almudena, he does not tell the reader. The latter is given only the Spanish word Almudena; and one must, therefore, return to it for further consideration of its connotative values.

It has been repeatedly demonstrated that the symbolic values in the names Galdós gave his characters are often quite apparent. ${ }^{12}$ Consequently, one is justified in turning to the most obvious referent known to Galdós and the majority of his Madrilenian readers-i.e., the "Almudena," the cathedral of the patroness of Madrid. More than any other church in Madrid, it is the traditional and official spiritual center of the city. It not only marks the spot where the first place of public worship was erected in Madrid, but it has also traditionally housed the sanctuary where rulers of the city and later those of modern Spain attended services. The first obligation of royalty upon entering Madrid was always to pay a visit to the "Almudena." All important processions started there ${ }^{13}$ and Mesonero Romanos reported in 1833, "el ayuntamiento celebra en ella sus funciones. . . ."14 Significantly, it is the largest of all churches in the capital, and it stands immediately south of, and adjacent to, the grounds of the Royal Palace.15

Like Galdós' character, Madrid's "Almudena" had other religious experiences before being dedicated to the Virgin. Most notably, it was the principal Moslem mosque of the city at the time of the Reconquest. If not the actual brick and mortar descendant of an earlier Jewish synagogue (as some claim), ${ }^{16}$ it was, of course, a spiritual descendant of Judaism. ${ }^{17}$ On November 9, 1085, Alfonso VI and his clergy purified the edifice, consecrating it to the "Virgen de la Almudena, así llamada por haber sido hallada una imagen [de ella] cerca del Almudit [—Almudín] o depósito de trigo."18

The history of this hallowed place has a parallel in the personal history of Galdós' character Almudena. He was born of Jewish parents, given the Hebrew name Mordejai, and learned the rudiments of Judaism. He next acquired some aspects of the Islamic religion, is considered a Moslem by some Galdosian characters, ${ }^{19}$ and in his very first appearance, Almudena speaks of rosaries (p. 1883)-an Islamic contribution to Christianity. Upon his arrival in Madrid, Almudena accepted Christian baptism (p. 1954). However, as Alfonso VI's purification of the city's mosque could not remove the earlier Semitic basis and practices of Christianity (which Galdós understood and often delighted in expounding), ${ }^{20}$ the baptism of Almudena failed to wash away his earlier religious experiences and he always considers himself basically Hebraic (pp. 1908, 1954). He is, as Robert Ricard has so skillfully demonstrated, a composite Semite-a personification of the three great religions which have existed on Spanish soil..21 This definition seems especially applicable to the official, historical religious tradition in 
the Spanish capital (where all the action of the novel takes place), because only when referring to Madrid is the name Almudena of significance. ${ }^{22}$

As a character who incarnates aspects of Madrid's official and traditional religion, Almudena, of course, has spiritual antecedents which are as old as humanity itself. Thus Galdós concludes a description of Almudena praying alone in the desolate outskirts of the city by saying his action represents "un caso de atavismo o de retroacción instinctiva hacia la antigüedad, . . . en que se inició la vida de la raza" (p. 1954). Almudena, in this instance, believes he is on Mount Sinai, the hallowed starting place of the entire JudeoChristian-Islamic religious tradition.

Later Galdós associates Almudena specifically with the very early religious history of Madrid by changing his mendicant post, in the climactic moments of the novel, to the Church of San Andrés, el Apóstol. At this church there is a priest who has taken a special and generous interest in Almudena precisely because he is a Semite. "Algo arabista y hebraizante, [Padre Mayoral, ${ }^{23}$ el coadjutor] solía echar algún párrafo con él." Shortly thereafter the author mentions a specific instance in which the cleric "se dignó parlotear un rato con Almudena en lengua arábiga" (p. 1960). Of all the parishes in Madrid, this is the most appropriate one for Galdós to bring his composite (and baptized) Semite into contact with such a fictitious ${ }^{24}$ priest, because the original function of the San Andrés Church was to counterbalance and to serve the aljamathe quarter of both Moslem and Jews after the reconquest of Madrid. ${ }^{25}$ Thus, in a sense, Almudena's return ${ }^{26}$ to San Andrés is another case of atavism, for the Moorish beggar and the coadjutor re-enact a scene and renew a relationship which were common there during the early history of Madrid.

Other examples could be cited ${ }^{27}$ but it seems clear, just as Galdós wished to create a composite religious Semite (demonstrated, as already noted, by Ricard), he also desired to indicate that Almudena is associated with moments of religious experience that cover a vast expanse of time. Thus it is no surprise to note that even Almudena's manner of speaking is nearly timeless-that is to say, he speaks exclusively with infinitive and gerund forms of the verb rather than with the customary inflected forms which denote time. ${ }^{28}$

Significantly, Almudena and Benina (the protagonist) are first seen in a church when the novel opens. Galdós highlights this fact by moving with camera-like increasing focus (and employing elements of suspense) from outside the church, to the inside-"según se entra" (p. 1880), and then even further-"más adentro ..." (p. 1881), until he introduces Almudena and Benina.

When the two leave the sanctuarytheir common starting place-for fictional adventures in the horrible slums of south Madrid, it is only Benina (long recognized as the incarnation of practical kindness and charity) who is able to sustain and help so many others. Although historians claim that many individual Madrilenians and the Spanish nation itself have been miraculously aided in times of great need by recourse to the "Almudena," ${ }^{29}$ Galdós' character is not only unable to give succor to others, but must soon himself be cared for by Benina. ${ }^{30}$. The latter is too busy for formal religious exercises; never once does she attend Mass, say the rosary, or the like. Blind Almudena ${ }_{\star}$ on the other hand, does spend considerable time in traditional, officially prescribed prayers-most notably upon a pile of trash in the Madrid city dump, which he mistakenly believes (as mentioned above) to be Mount Sinai (p. 1953). ${ }^{31}$ Benina joins him, not in any sense because she responds to an almuédano-like call or inspiration to prayer, but simply for the more practical reasons of 
bringing Almudena his lunch and warning him not to get sunburned (pp. 1952-53). Their fundamentally different concepts of life and reality may be demonstrated by their discussion of Benina's arrival. Almudena, the man of religion, believes she was sent down from Heaven. Benina, the pragmatist, knows, however, that such heights of effective personal service are reached only after a long, arduous climb (pp. 196061).

Sherman Eoff has expressed an almost universally accepted opinion when he says, "if Galdós had been asked to state his concept of religion, he probably would have been satisfied to point to Benina as a living illustration. ..." ${ }^{32}$ Benina is clearly Galdós' heroine; Almudena is the contrasting foil who aids in her presentation and delineation. ${ }^{33}$ Galdós created Almudena exclusively for the novel Misericordia and never has him appear except in the company of Benina. Although he is exotic and has a rich historical heritage, Almudena's miraculous promises of a better life (pp. 1908, 1930, 1942, 1954)-"producto natural de su sangre semítica y de su rica imaginación" (p. 1942)-all vanish under the cold examination of reason. ${ }^{34}$ His schemes are as false as the well-known spurious effigy of the Virgen de la Almudena, "la que durante muchos años [1830-88 ${ }^{35}$ estuvo en la hornacina de la cuesta de la Vega y que los ignorantes tenían por milagrosa. ... ${ }^{\prime 36}$ Like so many of the antipathetic, wealth-seeking characters toward whom Galdós wished to show his personal disapproval, Almudena is significantly yellowcomplexioned. ${ }^{37} \mathrm{He}$ is also literally bigmouthed (p. 1886), blind, ${ }^{38}$ confused, ludicrous, and-in the end-sick. Galdós was not in the habit of equivocating with such metaphors and this state of being certainly concurs with his evaluation at this time of the social effectiveness of organized, traditional religion-especially in comparison with the spirit and good works demonstrated by Benina. ${ }^{39}$
Thus Galdós' Almudena is, in many ways, clearly a connotatively symbolic character, participating in an allegorical novel (Misericordia) vis-à-vis a clearly allegorical protagonist, Benina (from "Benigna," p. 1882). As Galdós created such a character-far exceeding in fictional role, personal delineation, and symbolic overtones the blind Moor in Cutanda's Doña Francisca-, he found it necessary to reject ${ }^{40}$ the earlier author's limited appellation of "Mongio, el vendedor de dátiles." Knowing well the history of Madrid, ${ }^{41}$ and repeating his technique of linking symbolic names with official buildings, ${ }^{42}$ Galdós (the frequently aggressive anticleric $)^{43}$ chose instead the more allegorical name of Almudena-one rich in evocative religious connotations from the very heart of oldest Madrid.

\section{NOTES}

1 Bulletin Hispanique, LXI (1959), 12-25, and Nueva Revista de Filología Hispánica, xv (1961), 297-308, respectively.

2 See, for example, Wm. H. Shoemaker, "Galdós' Literary Creativity: D. José Ido Del Sagrario,' Hispanic Review, xIx (1951), 232-233, as well as my "Galdós' Sephardic Types," Symposium, xvIr (1963), 94; and "Galdós' Use of Yellow in Character Delineation," Publications of the Modern Language Association of America, Lxxix (1964), pp. 158-163.

3 All references in this study to Misericordia are found in the Obras completas, ed. Sainz de Robles (Madrid, 1950), v, $2^{a}$ edición.

4 "Almudena," Enciclopedia Universal Ilustrada (Barcelona, Espasa, n.d.), rv, 869-870.

5 I (1857), 204.

6 Benina corrects him: "José María de la Almudena" (p. 1954). See also note 30.

7 Pérez Galdós, "Prefacio del autor," Misericordia (Buenos Aires, 1943), p. 8.

8 (Madrid, 1869).

9 There is increasingly more evidence to show that people very similar to Almudena and his family do live in this region. See Robert Ricard, "Tres notas galdosianas," El Museo Canario (1960), pp. 136-137.

10 Esteban Ibáñez, Diccionario español-baamarani (Madrid, 1954), p. 24. Note also p. xi, lines 6-16. Both the Spanish almuédano and the Berber Imudden derive from the Arabic al-mu'addin.

11 In the writing of Aita Tettauen and Carlos VI, en la rápita (both 1905), Galdós definitely used reference books and informants to collect 
Arabic words for these episodios. (See Robert Ricard, "Note sur la genèse de l' «Aita Tettauen. de Galdós," Bulletin Hispanique, xxxvir [1935], 473-477.)

12 See note 2 above.

13 Jerónimo de Quintana, Historia de la antigïedad, nobleza y grandeza de la villa de Madrid, ed. E. Varela Hervías (Madrid, 1954), pp. 132-146.

14 Manual de Madrid, pp. 136-137.

15 See notes 12 and 13 above, and, among other works, Antonio Álvarez y Baena, Compendio histórico de las grandezas de la coronada villa de Madrid (Madrid, 1786), pp. 53-57; Luis Araujo-Costa, El barrio de palacio (Madrid, 1952), pp. 15-18; and José Amador de los Ríos, Historia de la villa y corte de Madrid (Madrid, $1860)$, pp. 127-128 and 152-153.

16 The authoritative Francisco Cantera Burgos, Sinagogas españolas (Madrid, 1955), pp. 241242 , fails to give confirmation to this assertion by local enthusiasts who insinuate a triumph for Catholicism over earlier religions. Some even claim that a Roman temple once stood on the site.

17 Galdós understood well that both Islam and Christianity were daughter religions of Judaism. For a comparative treatment of the three beliefs, see his Aita Tettauen (parts 3 and 4) and Carlos VI, en la rápita (part 1).

18 See note 4 above. For a more modern and less miraculous explanation, see Antonio Capmani y Montpalau, Origen histórico y etimológico de las calles de Madrid (Madrid, 1863), p. 23. An alternate etymology is suggested by Corral Raya and Sanz García in Madrid es así (Madrid, 1953), p. 46.

19 And by Galdós himself in his "Prefacio del autor," p. 8, lines 18-21.

20 See among others, Walter T. Pattison, Benito Pérez Galdós and the Creative Process (Minneapolis, 1954), pp. 73-80, and my "Galdós' Sephardic Types," p. 96.

21 Bulletin Hispanique, LxI, 12-25.

22 Cf. the references in notes 4, 13, 14, 15 above, with Capmani, Origen histórico, pp. 2324, Hilario Peñasco y Carlos Cambronero, Las calles de Madrid (Madrid, 1889), pp. 53-54, and with F. C. Sainz de Robles, Madrid autobiográfica (Madrid, 1951), p. 74. According to tradition, when the Madrilenians restored the Virgin to her church after the reconquest, the image was heard to promise, "Sólo para vosotros." (Ricardo Sepúlveda, "Santa María de la Almudena," Revista de España, cxxxrr [1891], 61.) 23 Even this choice of the name Mayoral seems to indicate that Galdós may have had Madrid's "Almudena" in mind because the street which runs in front of the cathedral is called "Mayor." 24 Although all records at the San Andrés Church were destroyed in the early days of the Civil War, the present administrators have expressed to me their opinion that such persons as the coadjutor Mayoral and Almudena could have participated in the scenes described at their church only hundreds of years before Galdós' time. (Personal visit, July, 1961.)

25 The still extant "Calle de la Morería" (to the northwest) and the "Puerta de Moros" (just behind the church to the south) testify even today to the church's strategic position within the quarter.

26 Cf. p. 1960, lines 42-45.

27 Almudena, for example, recites Sephardic prayers from the fifteenth century, something a Berber Jew would probably never do. (Cf. Ricard, p. 19.)

28 These verbals are, of course, also clearly a part of the linguistic difficulties of a non-native speaker of Spanish. They are, however (as suggested in the text of this study), also in harmony with other aspects of Almudena's characterization. Samuel Beckett's blind character, Pozo, in En attendant Godot (Paris, 1952), says categorically, "Les aveugles n'ont pas la notion du temps" (p. 147).

29 Quintana, Historia, p. 146.

30 This, of course, is a major message of the novel. Even such a social outcast as Almudena is worthy of compassion and charity; and, on a higher symbolic level, traditional religion must be attended by kindness and effective good works.

31 With her customary pragmatic candor, Benina replies: "Donde tú estás es en Babia" (p. 1953).

32 The Novels of Pérez Galdós (St. Louis, 1954), p. 130.

33 Cf́. Joaquín Casalduero, Vida y obra de Galdós (Madrid, 1951), p. 252; and Eoff, The Novels of Pérez Galdós, p. 20.

34 Benina realizes that one is but a ridiculous scheme to rob a bank (p. 1942).

35 Peñasco y Cambronero, Las calles, p. 548.

36 Antonio Velasco Zazo, Culto de ayer $y$ de hoy (Madrid, 1943), p. 38.

37 See my "Galdós' Use of Yellow in Character Delineation," Publications of the Modern Language Association of America, LxxIx (1964), pp. 158-163.

As the largest and most prominent church in Madrid, the "Almudena" required large amounts of money. The ruling families of Spain were often quite lavish in their donations and the Madrid city council was also generous-until the liberal revolution of 1868 . Then the government severed all financial support of the "Almudena" and almost immediately (Oct. 25, 1868) razed the building completely. However, in the 1880 's and early 1890's, even before Galdós wrote Misericordia, public and private funds were again being solicited; and by 1911, enough of the present cathedral was completed to allow the Virgin to be enthroned again. (See especially Sepúlveda, "Santa María," passim.) 38 Notably only regarding external reality and not, he claims, to matters of the spirit ( $p$. 1912). 39 Only two years earlier (1895), for example, Galdós created the title hero for Nazarin who becomes effective and Christlike in his ministry 
only when he disregards the Church and its regulations and (like Benina) follows his own inclinations.

${ }_{40}$ Galdós used some names which occur in Cutanda's work. See Fradejas Lebrero, "Para las fuentes de Galdós," Revista de literatura, IV (1953), 327.

41 Cf. 'H. Chonon Berkowitz, Pérez Galdós. Spanish Liberal Crusader (Madison, 1948), p. 106. Galdós also owned a number of books containing the history of the "Almudena," among others, those catalogued as numbers 3819 and 3843 by Berkowitz in his La biblioteca de Pérez Galdós (Las Palmas, 1951). Turned down pages, marginal comments, and underlinings indicate that Galdós utilized much information from these books. (Personal notes of W. T. Pattison [Univ. of Minnesota] who examined Galdós' library, lent to the present investigator.)

42 For example, in $\mathrm{La}$ de Bringas (1884), Galdós placed the title protagonist's family in the royal palace (just opposite the "Almudena") and gave the same names as the ruling family: Francisco, Isabel, and Alfonso.

43 Previous authors had always used the name "Almudena" with the greatest reverence. In 1891, Ricardo. Sepúlveda warned, "lo que Quintana, López de Hoyos, Gil González de Avila, Vera Tasis, Lope de Vega y otros han dicho respecto a la tradición santa de la Almudena, no debe ser impugnado ni contradicho por nadie
. . . porque el resultado sería funesto .... podría ser tan grande que quebrantase el equilibrio social." (Santa María de la Almudena," p. 183.)

This is, of course, the kind of challenge that would have delighted Galdós. As a liberal crusader, he had no compunctions about disturbing the "equilibrio social," because he frequently expressed the opinion that the Spanish nation would be better off without the twin control agencies of the Church and the monarchy.

At the present time, the traditional close relationship of the "Almudena" and the government has been restored. The cathedral is being rebuilt (after war damage); and on November 10, 1948, the Virgen de la Almudena was officially crowned, with Papal blessings and government sponsorship, patroness of Madrid and elevated to the honorary rank of "Capitán General" of the Army. (Breve noticia histórica de la imagen de María Santísima, la real de la Almudena, patrona de Madrid [n.p., n.d.pamphlet obtainable at the cathedral], pp. 1316.)

A skillful but conventional use of the name "Almudena" in the creation of a major character by a post-Galdosian novelist is found in Ramón Ledesma Miranda's Viejos personajes (Madrid, 1936), pp. 36, 229-230, et passim. This novel is frequently advertised as Almudena o viejos personajes.

\section{"IBEROAMERICA," THE HISPANIA ANTHOLOGY}

Contribute to the success of the AATSP's efforts to improve intercultural understanding in the Americas through the publication and distribution of Iberoamérica, sus lenguas y literaturas vistas desde los Estados Unidos. Full details appeared on p. 3-8 of our May 1962 issue, and further information is also printed in the Editorial in the September 1962 issue, pp. 503-504. It was also reviewed in the December 1962 issue of HISPANIA. Copies are $\$ 3.00$. Airmail your order (personal check or money order) payable to STUDIUM, Apartado 20979 - Adm. 32, México 1, D.F.

\section{STUDENT MEMBERSHIPS}

Please remind your students-and other teachers' students-that they may join the AATSP for $\$ 3.00$, receive Hispania, and enjoy all other privileges of membership, except the right to vote. 